\title{
Potensi diagnostik pencitraan ultrasonografi pada otot perineal sebagai sarana diagnosa penunjang kesehatan reproduksi sapi
}

\author{
Sari Yanti Hayanti ${ }^{1}$, Amrozi $^{2}$, Aryogi $^{3}$, Mokhamad Fakhrul Ulum $^{2} *$ \\ ${ }^{1}$ Program Studi Biologi Reproduksi, Sekolah Pascasarjana, Institut Pertanian Bogor \\ ${ }^{2}$ Departemen Klinik, Reproduksi, dan Patologi, Fakultas Kedokteran Hewan, Institut Pertanian Bogor, Bogor \\ ${ }^{3}$ Loka Penelitian Sapi Potong (Lolit Sapi), Badan Litbang Pertanian, Grati, Pasuruan
}

\begin{abstract}
ABSTRAK: Otot perineal salah satu bagian tubuh yang dapat terpengaruh oleh perubahan pada organ yang disokongnya seperti ekor, kolon dan saluran reproduksi. Pendekatan diagnostik pada perubahan ini berpotensi sebagai teknik baru dalam penegakan diagnosa yang terukur pada ternak sapi. Pencitraan ultrasonografi otot perineal pada sapi dapat dikembangkan menjadi metode noninvasif dalam memantau perubahan yang terjadi pada saluran reproduksi. Ultrasonografi mode brightness dengan transduser linear berfrekuensi $5 \mathrm{MHz}$ diposisikan pada otot perineal, yaitu otot coccygeus dan levator ani pada sudut pandang longitudinal dan transversal. Citra yang dihasilkan menampilkan variasi ekogenitas pada susunan jaringan kulit dan subkutan, otot coccygeus dan levator ani, dan peritoneum. Ukuran dan ekogenitas jaringan dapat diukur secara kuantitatif menggunakan perangkat lunak ImageJ.
\end{abstract}

Kata kunci:

Ultrasonografi, transperineal, otot coccygeus, otot levator ani, sapi

\section{- PENDAHULUAN}

Ultrasonografi (USG) merupakan alat pencitraan berbasis gelombang suara dengan frekuensi sangat tinggi dapat digunakan untuk mencitrakan jaringan lunak seperti otot secara noninvasif. Gelombang suara USG yang diatur berdasarkan frekuensi tertentu dapat menjangkau target citra jaringan, termasuk otot perineal. Otot perineal terdiri atas otot coccygeus, levator ani dan eksternal spincter ani. Otot perineal merupakan otot tubuh bagian belakang baik pada manusia maupun pada hewan yang berfungsi untuk menyokong organ terutama organ reproduksi yang berada di ruang pelvis (Herschorn 2004). Fungsi tersebut dapat menyebabkan adanya pengaruh pada citra ultrasonografi otot secara tidak langsung jika terjadi perubahan ukuran organ reproduksi (Ulum et al. 2017).

Otot yang mengalami perubahan dapat diamati melalui sonogram yang diperoleh dari pencitraan USG (Draghi et al. 2013). Perubahan dapat berupa ketebalan jaringan otot maupun ekogenitas pada citra ultrasonografi, seperti yang telah dilaporkan terjadi pada otot coccygeus sapi perah (Ulum et al. 2017). Studi ini menjelaskan lebih detil metode pencitraan otot perineal (coccygeus dan levator ani) yang belum banyak dilakukan pada hewan besar seperti ternak sapi.

\section{- MATERI DAN METODE}

Bahan: Studi ini menggunakan sapi induk, unit kandang handling ternak, unit USG (SIUI CTS-900V) probe linear frekuensi $5.0 \mathrm{MHz}$, unit alat cukur elektrik, plastik glove, gel USG, pisau cukur, sabun dan air.
Metode: Pencitraan USG transperineal dilakukan saat sapi berada dikandang jepit. Pencitraan dilakukan secara transkutan pada bagian perineal baik posisi sebelah kanan maupun kiri. Rambut pada daerah pencitraan dicukur sejajar dengan letak otot coccygeus dan levator ani. Permukaan kulit dibasahi dengan air sabun dan pencukuran dilakukan dengan panjang (arah longitudinal) $\pm 15 \mathrm{~cm}$ dan lebar (arah transversal) $\pm 10 \mathrm{~cm}$ dengan sisa rambut yang tertinggal \pm 3 $\mathrm{mm}$. Permukaan kulit diberi gel USG sebelum pencitraan.

Pencitraan pada otot coccygeus dan levator ani dilakukan pada sudut pandang longitudinal dan transversal. Proses pencitraan dilakukan dengan cepat berkisar antara 5-10 detik untuk mendapatkan satu sonogram dari masing-masing sudut pandang. Citra USG selanjutnya diintepretasikan sesuai dengan tujuan. Analisa lebih lanjut citra digital dapat menggunakan perangkat lunak ImageJ atau perangkat lunak lainnya yang umum digunakan untuk memproses gambar.

\section{- HASIL DAN PEMBAHASAN}

Tahapan USG transperineal terdiri pencukuran, pemberian gel USG, dan pencitraan serta analisa hasil citra. Alat cukur elektrik dapat digunakan untuk mempermudah dalam menentukan sisa panjang rambut merata sepanjang area pencukuran (Al Maqbali 2016). Sisa rambut yang pendek dapat mengurangi hambatan perambatan gelombang suara

Diterima: 30-03-2020 | Direvisi: 28-04-2020 | Disetujui: 01-05-2020

(C) 2020 CC-BY-SA. Ini adalah artikel Open Access yang didistribusikan berdasarkan ketentuan dari Creative Commons Attribution ShareAlike 4.0 International License (https://creativecommons.org/licenses/by-sa/4.0/). 
USG saat proses pencitraan sehingga dapat dihasilkan citra yang baik. Kulit permukaan yang dibasahi dengan air sabun sebelum pencukuran dapat mempercepat waktu pencukuran ( $<5$ detik). Proses pencukuran yang cepat dapat mencegah terjadinya peningkatan kortisol oleh adanya rasa tidak nyaman pada kuda (Schönbom et al. 2015).

Gel USG berfungsi untuk memaksimalkan rambatan gelombang suara mencapai target objek yang akan dicitrakan (Al-Nima et al. 2019). Pencitraan dilakukan dengan memastikan posisi otot coccygeus dan levator ani terlebih dahulu. Otot coccygeus terletak dari tulang belakang ischium sampai ke tiga tulang pertama caudal vertebrae dan otot levator ani dari tulang belakang ischium sampai ke eksternal spinchter anal caudal fasia (Budras \& Habel 2003). Pencitraan transperineal otot coccygeus dilakukan dengan meletakkan probe pada area yang mendekati cauda vertebrae dan pada otot levator ani yang mendekati ke eksternal cauda fascia.

Ilustrasi teknik pencitraan transperienal dan hasil citra dapat dilihat pada Gambar 1. Citra jaringan yang tampak pada pencitraan USG otot perineal adalah kulit, subkutan, otot, dan peritoneum. Jaringan kulit dan subkutan tampak memiliki ekogenitas hipoekoik, otot coccygeus dan levator ani tampak dengan ekogenitas yang mendekati anekoik. Fasia pembungkus otot dan peritoneum tampak hiperekoik.

A

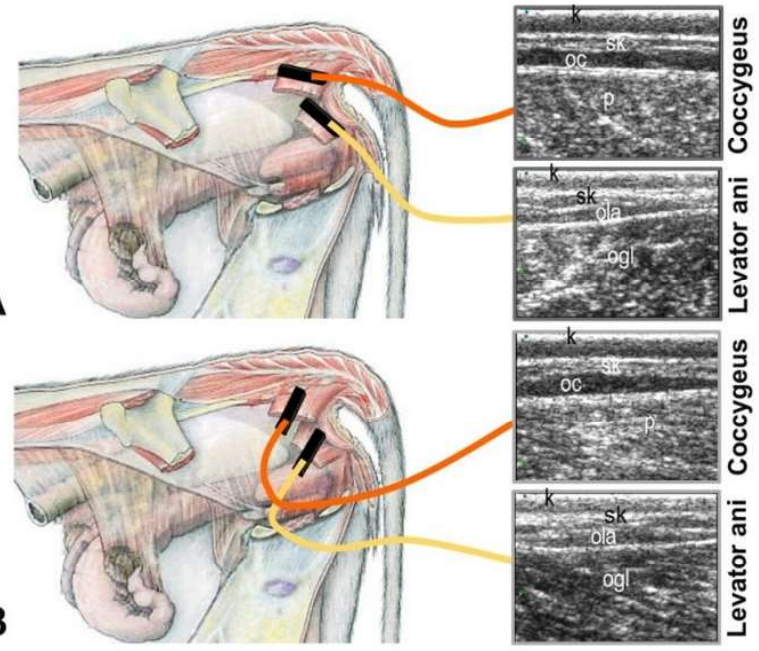

Gambar 1. USG Transperienal pada sapi (anatomi otot diadopsi dari Budras \& Habel 2003). A = longitudinal, B = transversal. Keterangan: $\mathrm{k}=$ kulit, $\mathrm{sk}=$ subkutan, $\mathrm{oc}=$ otot coccygeus, $\mathrm{p}=$ peritoneum, ola $=$ otot levator ani, ogl $=$ otot gluteus.

Ekogenitas dan ukuran otot mengalami perubahan jika terjadi trauma atau pembebanan yang dialami jaringan. Hematoma akibat trauma menyebabkan perubahan intensitas dan tebal pada otot. Intensitas otot hematoma dalam 24 jam pertama akan tampak perpaduan hiperekoik dan hipoekoik, sedangkan pada hari berikutnya akan tampak hipoekoik hingga anekoik dengan tebal otot mengalami peningkatan (Draghi et al. 2013). Gangguan reproduksi berupa nymphomania, dimana terjadi aktifitas berlebih pada otot akibat pergerakan ekor sehingga terbentuk tanduk ekor yang juga dapat merubah intensitas dan ukuran otot (Hillman \& Gilbert 2008). Da- lam hal pembebanan kerja otot, otot coccygeus pada sapi perah bunting memiliki perbedaan ukuran dan intensitas jika dibandingkan dengan saat tidak bunting dan saat pascalahir (Ulum et al. 2017)

\section{- SIMPULAN}

Otot perineal pada sapi yaitu coccygeus dan levator ani dapat dicitrakan secara ultrasonografi secara transperineal dengan mudah dan cepat. Citra yang dihasilkan dapat dimanfaatkan baik untuk tujuan diagnosis kelainan atau perubahan pada jaringan organ reproduksi yang disokongnya.

\section{- INFORMASI PENULIS}

Penulis untuk Korespondensi

*MFU: ulum@ipb.ac.id

Depertemen Klinik, Reproduksi, dan Patologi, Fakultas Kedokteran. Institut Pertanian Bogor. J1. Agatis Kampus IPB Dramaga Bogor 16680

\section{- TERIMA KASIH}

Peneliti mengucapkan terimakasih kepada Kementrian Pertanian melalui dana DIPA Badan Penelitian dan Pengembangan Pertanian, no. 49/Kpts/KP.320/H.1/9/2019, Loka Penelitian Sapi Potong, Dr Ir Dicky Pamungkas, MSc atas penggunaan alat dan induk sapi. Penulis juga mengucapkan terimakasih kepada drh. Dicky M. Dikman, M.Phil atas kerjasama dan bantuan pengambilan data, Bapak Akhmad, Muhammad Sumitro dan Nana Hari Kurniawan atas bantuan pengekangan induk sapi selama penelitian.

\section{- PUSTAKA ACUAN}

Al Maqbali MAH. 2016. Pre-operative hair removal: a literature review. International Journal of Nursing \& Clinical Practices. 3(2016):1-6. doi: 10.15344/2394-4978/2016/163.

Al-Nima AM, Al-Kotaji M, Al-Iraqi O, Ali ZH. 2019. Preparation and evaluation of ultrasound transmission gel. Asian Journal Pharmaceutical and Clinic Research. 12(1):422-427. doi: 10.22159/Ajpcr.2019.V12i1.30150.

Budras KD, Habel RE. 2003. Bovine anatomi an illustrated text. First edition. Schlütersche GmbH \& Co. KG, Verlag und Druckerei. HansBöckler-Allee 7, 30173 Hannover, Germany.

Draghi F, Zacchino M, Canepari M, Nucci P, Alessandrino F. 2013. Muscle injuries: ultrasound evaluation in the acute phase. Journal U1trasound. 16(4): 209-214. doi: 10.1007/s40477-013-0019-8.

Herschorn S. 2004. Female pelvis floor anatomy: the pelvis floor, supporting structures, and pelvis organs. Reviews in Urology. 6(5):2-10.

Hillman R, Gilbert RO. 2008. Chapter 9 - Reproductive diseases. In: Divers TJ, editor. Rebhun's diseases of dairy cattle (SF Peek. ed.). 2nd ed. Saint Louis: Saunders. pages:395-446.

Schönbom H, Kassens A, Hopster-Iversen C, Klewitz J, Piechotta M, Martinsson G, Kißler A, Burger D, Sieme H. 2015. Influence of transrektal and transabdominal ultrasound examination on salivary cortisol, heart rate, and heart rate variability in mares. Theriogenology. 83(4):749-56. doi: 10.1016/j.theriogenology.2014.11.010.

Ulum MF, Frastantie D, Purwantara B. 2017. Sonogram of coccygeus muscle in dairy cows with different gestational ages. Journal of Animal Science and Technology. 59(26):1-8. doi: 10.1186/s40781-0170152-6. 